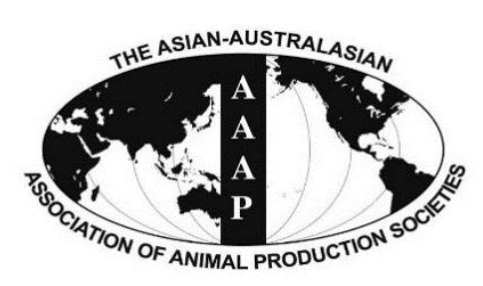

Open Access

Asian Australas. J. Anim. Sci.

Vol. 28, No. 8 : 1116-1122 August 2015

http://dx.doi.org/10.5713/ajas.14.0850

www.ajas.info

pISSN 1011-2367 elSSN 1976-5517

\title{
Influence of Sunflower Whole Seeds or Oil on Ruminal Fermentation, Milk Production, Composition, and Fatty Acid Profile in Lactating Goats
}

\author{
T. A. Morsy, S. M. Kholif, A. E. Kholif, O. H. Matloup, A. Z. M. Salem ${ }^{1, *}$, and A. Abu Elella ${ }^{2}$ \\ Dairy Science Department, National Research Center, Dokki, Giza, 12311, Egypt
}

\begin{abstract}
This study aimed to investigate the effect of sunflower seeds, either as whole or as oil, on rumen fermentation, milk production, milk composition and fatty acids profile in dairy goats. Fifteen lactating Damascus goats were divided randomly into three groups $(n=5)$ fed a basal diet of concentrate feed mixture and fresh Trifolium alexandrinum at 50:50 on dry matter basis (Control) in addition to $50 \mathrm{~g} / \mathrm{head} / \mathrm{d}$ sunflower seeds whole (SS) or $20 \mathrm{~mL} / \mathrm{head} / \mathrm{d}$ sunflower seeds oil (SO) in a complete randomized design. Milk was sampled every two weeks during 90 days of experimental period for chemical analysis and rumen was sampled at 30, 60, and 90 days of the experiment for ruminal $\mathrm{pH}$, volatile fatty acids (tVFA), and ammonia-N determination. Addition of SO decreased ( $\mathrm{p}=0.017$ ) ruminal $\mathrm{pH}$, whereas SO and SS increased tVFA $(p<0.001)$ and acetate $(p=0.034)$ concentrations. Serum glucose increased $(p=0.013)$ in SO and SS goats vs Control. The SO and SS treated goats had improved milk yield $(\mathrm{p}=0.007)$ and milk fat content $(\mathrm{p}=0.002)$. Moreover, SO increased milk lactose content $(p=0.048)$ and feed efficiency $(p=0.046)$ compared to Control. Both of SS and SO increased $(\mathrm{p}<0.05)$ milk unsaturated fatty acids content specially conjugated linolenic acid (CLA) vs Control. Addition of SS and SO increased $(\mathrm{p}=0.021) \mathrm{C} 18: 3 \mathrm{~N} 3$ fatty acid compared to Control diet. Data suggested that addition of either SS or SO to lactating goats ration had beneficial effects on milk yield and milk composition with enhancing milk content of healthy fatty acids (CLA and omega 3), without detrimental effects on animal performance. (Key Words: Fatty Acid Profile, Lactating Goats, Milk Composition, Sunflower Seeds, Sunflower Oil)
\end{abstract}

\section{INTRODUCTION}

Goat milk has been identified as an alternative for human consumers who are either sensitive or allergic to cow's milk (Dixit et al., 2012). Lipid composition is one of the most important components of the nutritional quality of goat milk. The nutritional advantage of goat milk fat compared to cow's milk may been attributed to the high content of C6:0 to C10:0 fatty acids (FA), the high percentage of the short- and medium-chain FA, and to the small size of fat globules; hence making goat's dairy

\footnotetext{
* Corresponding Author: A. Z. M. Salem Tel: +20-521-722-29655-42, Fax: +20-521-722-180-61-94, E-mail: asalem70@yahoo.com

${ }^{1}$ Facultad de Medicina Veterinaria y Zootecnia, Universidad Autónoma del Estado de México, C.P. 50000, Estado de México, México.

2 Animal Production Research Institute, Agriculture Research Center, Dokki, Cairo, 12618, Egypt.

Submitted Nov. 3, 2014; Revised Feb. 2, 2015; Accepted Feb. 11, 2015
}

product easily digestible than cow's dairy product (Chilliard et al., 2006). However, goat milk contains a high proportion of saturated FA (SFA); the consumption of which is considered a risk factor for human cardiovascular disease (Ney, 1991). Ruminant milk FA composition can be changed significantly in response to feeding regimen, especially lipid supplementation, which has variable effects depending on the lipid added and its interaction with the type and proportion of forage and concentrate in the diet (Chilliard et al., 2007; Kholif et al., 2014).

Addition of seeds oil to lactating dairy cows ration was one of the methods to change the proportion of total unsaturated FA (TUFA) in milk fat by about $40 \%$, although extensive biohydrogenation occurs normally in the rumen (Dschaak et al., 2009). Sunflower whole seeds would be a good choice from a consumer point of view, as it is rich in polyunsaturated FA (PUFA). Sunflowers being a source of linoleic acid (66\% of total FA), which is an n-6 FA (Ebrahimi et al., 2014). Whole seeds of sunflowers do not 
have antinutritional factors such as those found in the other major oilseeds, including soybeans, cottonseeds and rapeseeds. For this reason, it is considered to be a safe feed ingredient for all species.

Due to high oil content, sunflower seeds are used as an energy source. However, they are particularly valued if used as a supplement for the dietary management of the FA profile of dairy and meat products. This may be since sunflower seeds whole (SS) and sunflower seeds oil (SO) are rich in PUFA and conjugated linoleic acid (CLA), which have proven beneficial effects on human health (Peng et al., 2010). Feeding SS resulted an increase of CLA, C18:2 and omega- 6 content in milk and meat of ruminant animals (Ebrahimi et al., 2014). Beauchemin et al. (2009) noted increased lag time of fiber degradation in the rumen and in methane emissions reduction with sunflower seeds as a feed additive. Seeds of sunflower can improve rumen bacterial activity and increase total bacteria and subsequent bacterial amino acid flow through reducing the rumen protozoa and rumen bacteria predators (Ivan et al., 2004). Therefore, the objective of this study was to evaluate the impact of SS or SO on lactating Damascus goat's milk yield and CLA content, in order to develop a practical feeding strategies for goat production systems.

\section{MATERIALS AND METHODS}

\section{Study location}

The present study was carried out at the dairy science department, National Research Centre, Egypt and the experimental farm of Animal Production Research Institute, Gemazza, Egypt.

\section{Animals housing and feeding}

Fifteen lactating Damascus goats with an average live body weight of $44.8 \mathrm{~kg}$ and in the $3 \mathrm{rd}$ or 4 th lactating seasons were randomly divided into three equal and similar groups to be fed a basal diet individually.

Goats were fed a basal diet (concentrate feed mixture [CFM]) and fresh Trifolium alexandrinum (1:1, on dry matter [DM] bases) of $142.0 \mathrm{~g} / \mathrm{kg}$ crude protein $(\mathrm{CP})$ and $142.0 \mathrm{~g} / \mathrm{kg}$ crude fiber (CF). Three treatments (5 goats/treatment) were (Control) (basal diet with no additive; the same control treatment of Kholif et al., 2015), SS (Control plus a daily dose of $50 \mathrm{~g} / \mathrm{head} / \mathrm{d}$ of $\mathrm{SS}$ ) or $\mathrm{SO}$ (Control plus a daily dose of $20 \mathrm{~mL} / \mathrm{head} / \mathrm{d}$ of SO). The additives (i.e., whole seeds or oil) were mixed with about $100 \mathrm{~g}$ of the concentrates before morning feeding at $08.00 \mathrm{~h}$ and fed to goats. The offered feeds were assessed to cover the maintenance and production requirements for each goat (NRC, 2007). Chemical composition of CFM and Trifolium alexandrinum is shown in Table 1. The CFM was offered individually for each animal once daily at $08.00 \mathrm{~h}$, while
Table 1. Chemical composition (\%) of the concentrate feed mixture $\left(\mathrm{CFM}^{1}\right)$, fresh Trifolium alexandrinum, sunflower seeds whole ${ }^{2}$ or oil ${ }^{3}$ and the basal $\operatorname{diet}^{4}$ (on DM basis)

\begin{tabular}{lcccc}
\hline & CFM & $\begin{array}{c}\text { Trifolium } \\
\text { alexandrinum }\end{array}$ & $\begin{array}{c}\text { Sunflower } \\
\text { whole seeds }\end{array}$ & $\begin{array}{c}\text { Basal } \\
\text { diet }^{4}\end{array}$ \\
\hline Dry matter & 91.3 & 13.3 & 91.6 & 52.3 \\
Organic matter & 89.9 & 88.2 & 96.5 & 89.1 \\
Crude protein & 14.2 & 14.2 & 21.7 & 14.2 \\
Ether extract & 4.1 & 2.6 & 40.3 & 3.35 \\
Crude fiber & 15.3 & 27.5 & 22.6 & 21.4 \\
$\begin{array}{l}\text { Nitrogen } \\
\text { free-extract }\end{array}$ & 56.4 & 43.9 & 11.9 & 50.2 \\
\hline
\end{tabular}

${ }^{1}$ The CFM consisted of $25 \%$ undecorticated cotton seed meal, $35 \%$ wheat bran, $30 \%$ corn, $3 \%$ rice bran $3 \%$ molasses, $2 \%$ limestone, $1 \%$ urea and $1 \%$ salt $(\mathrm{NaCl})$.

${ }^{2}$ Sunflower whole seeds contain (individual fatty acids, $\%$ of total fatty acids): C16:0, 6.4; C18:0, 5.7; C18:1, 22.6; C18:2, 65.0, C18:3, 0.3.

${ }^{3}$ Sunflower oil seeds contain (individual fatty acids, $\%$ of total fatty acids): C16:0, 5.4; C18:0, 4.6; C18:1, 21.0; C18:2, 69.0.

${ }^{4}$ The control diet consisted of CFM and fresh Trifolium alexandrinum at 1:1 (on DM basis); the same used in Kholif et al. (2015).

fresh Trifolium alexandrinum was offered at 10.00 and $16.00 \mathrm{~h}$ for 90 days. Dry matter intake was recorded daily throughout the experimental period by weighing the offered diets and refusals from the previous day. Drinking water was available at all time.

Samples of feed ingredient were analyzed for DM (ID 930.15), ash (ID 942.05), CP (ID 984.13), CF (ID 962.09) and ether extract (ID 945.16) according to methods of AOAC (1997). Nitrogen-free extract and organic matter were calculated by difference.

Samples of SS and oil were analyzed for FA content according to the method of AOAC (2007) using FA methyl esters prepared by base-catalyzed methanolysis of the glycerides $(\mathrm{KOH}$ in methanol). On a Perkin-Elmer chromatograph (model 8420, Beaconsfield, Perkin Elmer, Beaconsfield, UK) equipped with a flame ionization detector, the FA were separated. Helium was the carrier gas at $30 \mathrm{~cm} / \mathrm{sec}$, where column temperature was initially $150^{\circ} \mathrm{C}$ for $1 \mathrm{~min}$, and then increased by $4^{\circ} \mathrm{C} / \mathrm{min}$ to $200^{\circ} \mathrm{C}$, and was then held at $200^{\circ} \mathrm{C}$ for $10 \mathrm{~min}$. Individual $\mathrm{FA}$ methyl esters were identified by retention time with reference to methyl esters standards.

\section{Sampling and analysis of rumen liquor}

Rumen liquor samples were collected from three animals within each group by a stomach tube. Collection was performed four hours after morning feeding of concentrates, after 30,60, and 90 days of the experiment. Rumen samples were filtered through four layers of cloth and used quickly as possible for the measurement of $\mathrm{pH}$ using a digital $\mathrm{pH}$-meter. Strained rumen liquor was stored in glass bottles $(25 \mathrm{~mL})$ with few drops of toluene and paraffin oil just to cover the surface, and stored at a deep 
freeze $\left(-18^{\circ} \mathrm{C}\right)$ till chemical analysis. The concentration of ruminal ammonia-N was determined according to AOAC (2007). Ruminal total volatile FA (tVFA) and fractions of volatile fatty acids were determined by gas chromatography (Varian 3700; Varian Specialties Ltd, Brockville, ON, Canada).

\section{Sampling and analysis of blood serum}

Blood samples were withdrawn from the jugular vein of the same three animals which used for rumen liquor collection, after 30, 60, and 90 days after four hours of concentrates morning feeding. The collected blood samples were centrifuged at $4,000 \times g$ at $4^{\circ} \mathrm{C}$ for $20 \mathrm{~min}$. Serum was separated into clean dried glass vials and frozen at $-20^{\circ} \mathrm{C}$ till analysis. Blood serum samples were analyzed for concentrations of total protein, albumin, glucose, cholesterol and triglycerides using specific kits (Stanbio Laboratory, Boerne, TX, USA) as manufacturer instructions. Globulin concentration and albumin/globulin ratio (A/G ratio) were calculated.

\section{Sampling and milk composition and fatty acids analysis}

Individual milk samples were collected from all goats every two weeks during the experimental period (i.e., 90 days). Goats were hand milked twice daily at 08:00 and 16:00 $\mathrm{h}$ and the milk yield was recorded. The sample of each animal represents a mixed sample of constant percentage of the evening and morning yield. Milk samples were analyzed for total solids, fat, protein, non-protein $\mathrm{N}$ and lactose using infrared spectrophotometry (Foss 120 Milko-Scan, Foss Electric, Hillerød, Denmark). The ash content of milk was determined after heating milk sample in a muffle furnace at $550^{\circ} \mathrm{C}$ for $16 \mathrm{~h}$, and the solids not fat content was calculated by difference. Fatty acids in milk were determined as described previously in Kholif et al. (2014) using methyl esters prepared by base-catalyzed methanolysis of the glycerides (KOH in methanol) according to International Standards (ISO-IDF, 2002). Fatty acid methyl esters were separated using a Cp-Sil 88 fusedsilica capillary column $(100 \mathrm{~m} \times 0.25 \mathrm{~mm}$ i.d. $\times 0.2 \mu \mathrm{m}$ film thickness, Chrompack, Middelburg, Netherlands) on a Perkin-Elmer chromatograph (model 8420, Beaconsfield, Perkin Elmer, Beaconsfield, UK) equipped with a flame ionization detector.

\section{Statistical analysis}

Statistical analysis for the obtained data was carried out using the general linear model producers of SAS (SAS Inst. Inc. Cary, NC, 2006) in a complete randomized design using the following model:

$$
\mathrm{Y}_{\mathrm{ij}}=\mu+\mathrm{T}_{\mathrm{i}}+\mathrm{E}_{\mathrm{ij}}
$$

Where $\mathrm{Y}_{\mathrm{ij}}$ expressed every observation of the $j$ th animal in the $i$ th treatment, $\mu$ expressed the general mean, $\mathrm{T}_{\mathrm{i}}$ expressed the treatment effect, and $\mathrm{E}_{\mathrm{ij}}$ expressed the experimental error. Comparison among means was carried out using Duncan's Multiple Range Test (Duncan, 1955). Significance was declared at a level of $\mathrm{p}<0.05$ and trend of $\mathrm{p} \leq 0.10$ (Steel and Torrie, 1980).

\section{RESULTS AND DISCUSSION}

\section{Dry matter intake and rumen activity}

Live body weight of goats was not different $(p>0.05)$ among experimental groups which reflects the random distribution of goats into the treatments.

Goats of all experimental groups consumed approximately $(p>0.05)$ the same amount of feeds during the experimental period. These results were similar to that obtained by Petit et al. (2004) and Mohammed et al. (2011) who not found different in dry matter intake (DMI) among treatments have been reported in lactating cows fed whole, unprocessed sunflower and flaxseed seeds. Moreover, feeding sunflower whole seeds at $10 \%$ of cow's diet had no effect on DMI (Rafalowski and Park, 1982). However, greater DMI for cows fed whole flaxseed compared with those fed whole sunflower seeds have been previously reported (Petit, 2003).

Decreased ruminal $\mathrm{pH}$ values were occurred $(\mathrm{p}=0.017)$ due to SO and SS addition compared to Control (Table 2). Ruminal $\mathrm{pH}$ values for all treatments ranged between 5.8 and 6.2, which were within the range considered acceptable for fiber digestion (Ørskov and Ryle, 1990). Decreased ruminal $\mathrm{pH}$ values with $\mathrm{SS}$ and $\mathrm{SO}$ addition may be association with increased energy density (Fulton et al., 1979) or the increased concentrations of tVFA in both treatments compared to Control goats (Baile and Forbes, 1974).

Increased tVFA $(\mathrm{p}<0.001)$ and acetate $(\mathrm{p}=0.034)$ concentrations were obtained as a result of SO and SS addition to goats diet. No differences ( $p>0.05)$ were noted for propionate and butyrate concentrations among SS and SO or control goats. Total VFA concentration in the rumen depends on many factors including nutrient digestibility, rate of absorption, rumen $\mathrm{pH}$, rate of digesta passage from rumen, as well as the microbial population in the rumen and their activities (Flatt et al., 1956). The higher concentrations of tVFA with SS or SO indicate the more efficient anaerobic fermentation, which may be due to increased organic matter and fibers digestibility (Khattab et al., 2011). The higher of acetate proportion of treated groups may be possibly resulted from an increased cellulolytic bacteria activity in rumen with rations contained SS or SO.

Decreased concentrations of ruminal ammonia-N concentration $(p=0.046)$ were occurred when SS or SO 
Table 2. Goats weight, feed intake, and rumen fermentation kinetics of lactating Damascus goats fed basal diet with sunflower seeds whole (SS) or sunflower seeds oil (SO)

\begin{tabular}{|c|c|c|c|c|c|}
\hline & \multicolumn{3}{|c|}{ Diets $^{1}$} & \multirow{2}{*}{ SEM } & \multirow{2}{*}{ p-value } \\
\hline & Control & SS & SO & & \\
\hline Live body weight (kg) & 44.7 & 44.3 & 44.5 & 4.88 & 0.960 \\
\hline Dry matter intake $(\mathrm{kg} / \mathrm{d})$ & 1.36 & 1.42 & 1.39 & 0.018 & 0.357 \\
\hline \multicolumn{6}{|l|}{ Ruminal fermentation kinetics } \\
\hline $\mathrm{pH}$ value & $6.20^{\mathrm{a}}$ & $6.06^{\mathrm{a}}$ & $5.80^{\mathrm{b}}$ & 0.068 & 0.017 \\
\hline Total volatile fatty acids (tVFA, mmol/L) & $78.1^{\mathrm{b}}$ & $90.9^{\mathrm{a}}$ & $92.2^{\mathrm{a}}$ & 2.32 & $<0.001$ \\
\hline \multicolumn{6}{|l|}{ Individual VFA (mol/dL) } \\
\hline Acetate (C2) & $58.1^{\mathrm{b}}$ & $66.0^{\mathrm{a}}$ & $68.5^{\mathrm{a}}$ & 3.09 & 0.034 \\
\hline Propionate (C3) & 28.8 & 30.7 & 31.3 & 1.33 & 0.779 \\
\hline Butyrate (C4) & 10.2 & 12.6 & 14.2 & 0.97 & 0.280 \\
\hline $\mathrm{C} 2 / \mathrm{C} 3$ & 2.03 & 2.15 & 2.17 & 0.041 & 0.368 \\
\hline Ammonia-N (mg/L) & $283^{\mathrm{a}}$ & $271^{\mathrm{b}}$ & $269^{\mathrm{b}}$ & 15.7 & 0.046 \\
\hline
\end{tabular}

SEM, standard error of the mean.

${ }^{1}$ Diets consisted of concentrate feed mixture and fresh Trifolium alexandrinum (1:1; Control), or Control plus $50 \mathrm{~g}$ SS/head/d or Control+20 mL $\mathrm{SO} / \mathrm{head} / \mathrm{d}$.

Means at the same row with different superscript are significantly $(\mathrm{p}<0.05)$ different.

were added to goats diets (Table 2). Ruminal ammonia-N concentrations were ranged between 269 to $283 \mathrm{mg} / \mathrm{L}$ which were above the range ( 0.60 to $1.59 \mathrm{mM}$ ammonia-N) considered by Satter and Slyter (1974) to be sufficient for microbial $\mathrm{N}$ production. Ammonia-N level depends on many factors, including the dietary $\mathrm{CP}$ solubility as the main one. Reduction of ammonia-N concentrations in the SS and SO goats was paralleled with increased ruminal tVFA which considered as an indicator of higher fermentation rate and increased microbial protein synthesis (Kholif et al., 2014). Moreover, decreased ammonia-N with SS and SO reflects increased ammonia consumed by ruminal bacteria for production of microbial protein in the rumen.

\section{Blood biochemical parameters}

Addition of SS and SO to goat diets did not alter $(p>0.05)$ blood chemistry whereas serum glucose concentration was increased $(p=0.013)$ with the two additions in goats diets (Table 3 ). Increased serum glucose concentration with SS and SO may be due to increased tVFA concentration in the rumen of goats. It is of interest that blood serum glucose of the SS and SO groups followed the same trend as their milk yield, which may confirm results of Clark et al. (1977) who claimed a positive relationship between blood serum glucose and milk yield.

\section{Milk yield, composition and fatty acids profile}

Increased milk yield $(\mathrm{p}=0.007)$ and milk fat content $(\mathrm{p}$ $=0.002$ ) was obtained as a result of SO and SS addition to goat diets. Moreover, increased lactose content $(\mathrm{p}=0.048)$ with improved feed efficiency (milk yield/DMI; $\mathrm{p}=0.046$ ) was obtained with SO vs SS and control. No effects were occurred $(\mathrm{p}>0.05)$ for milk content of protein, total solids, solids not-fat, ash, and urea $\mathrm{N}$ as a result of SS and SO addition in the goat diets (Table 4).

Milk production was increased with SO and SS goats without increasing DMI; this phenomena reflects better utilization of feeds. The increased milk yield obtained with SS and SO diets may be due to the increased tVFA concentration in rumen of goats fed diets added with SS or $\mathrm{SO}$, and apparent increased in the efficiency of $\mathrm{N}$ utilization, as well as an increased conversion and availability of nutrients for milk synthesis. The current results are in agreement with those of Abu Ghazaleh and Holmes (2007) and Castro et al. (2009) who reported that addition of sunflower seeds oil to cows ration increased milk yield. However, other studies reported a reduction in milk production by fed on sunflower whole seeds (Petit et al., 2004; Mohammed et al., 2011) or no change as a result of addition sunflower oil (Ollier et al., 2009) or sunflower

Table 3. Blood serum parameters of lactating Damascus goats fed basal diet with sunflower seeds whole (SS) or sunflower seeds oil (SO)

\begin{tabular}{lccccc}
\hline & \multicolumn{3}{c}{ Diets $^{1}$} & \multirow{2}{*}{ SEM } & p-value \\
\cline { 2 - 4 } & Control & SS & SO & & \\
\hline Total protein (g/dL) & 6.43 & 6.74 & 6.76 & 0.721 & 0.392 \\
Albumin (g/dL) & 3.44 & 3.61 & 3.67 & 0.494 & 0.587 \\
Globulin (g/dL) & 2.99 & 3.13 & 3.08 & 0.410 & 0.871 \\
A/G ratio & 1.16 & 1.20 & 1.20 & 0.045 & 0.946 \\
Triglyceride (mg/dL) & 186 & 182 & 179 & 23.7 & 0.101 \\
Cholesterol (mg/dL) & 196 & 190 & 188 & 24.9 & 0.699 \\
Glucose $(\mathrm{mg} / \mathrm{dL})$ & $62.2^{\mathrm{b}}$ & $66.2^{\mathrm{a}}$ & $70.3^{\mathrm{a}}$ & 1.23 & 0.013 \\
\hline
\end{tabular}

SEM, standard error of the mean; A/G, albumin/globulin.

1 Diets consisted of concentrate feed mixture and fresh Trifolium alexandrinum (1:1; Control), or Control plus $50 \mathrm{~g} \mathrm{SS} / \mathrm{head} / \mathrm{d}$ or Control+20 mL SO/head/d.

Means at the same row with different superscript are significantly $(\mathrm{p}<0.05)$ different 
Table 4. Average daily milk yield and composition of lactating Damascus goats fed basal diet with sunflower seeds whole (SS) or sunflower seeds oil (SO)

\begin{tabular}{lccccc}
\hline & \multicolumn{3}{c}{ Diets $^{1}$} & \multirow{2}{*}{ SEM } & \multirow{2}{*}{ p-value } \\
\cline { 2 - 4 } & Control & SS & SO & & \\
\hline Milk yield (g/d) & $1,140^{\mathrm{b}}$ & $1,214^{\mathrm{a}}$ & $1,240^{\mathrm{a}}$ & 60.1 & 0.007 \\
Milk composition (\%) & & & & & \\
$\quad$ Fat & $3.96^{\mathrm{b}}$ & $4.19^{\mathrm{a}}$ & $4.32^{\mathrm{a}}$ & 0.050 & 0.002 \\
$\quad$ Protein & 3.16 & 3.26 & 3.26 & 0.027 & 0.271 \\
Lactose & $4.65^{\mathrm{b}}$ & $4.72^{\mathrm{ab}}$ & $4.96^{\mathrm{a}}$ & 0.046 & 0.048 \\
Total solids & 12.8 & 13.0 & 13.6 & 1.699 & 0.266 \\
Solids not fat & 8.86 & 8.88 & 9.30 & 1.165 & 0.511 \\
Ash & 0.88 & 0.87 & 0.89 & 0.094 & 0.276 \\
$\quad$ Urea N & 39.2 & 38.4 & 37.6 & 5.32 & 0.121 \\
Feed efficiency & $0.83^{\mathrm{b}}$ & $0.85^{\mathrm{b}}$ & $0.89^{\mathrm{a}}$ & 0.040 & 0.046 \\
$\quad$ Milk yield/DMI) & & & & & \\
\hline
\end{tabular}

SEM, standard error of the mean; DMI, dry matter intake.

1 Diets consisted of concentrate feed mixture and fresh Trifolium alexandrinum (1:1; Control), or Control plus $50 \mathrm{~g} \mathrm{SS} / \mathrm{head} / \mathrm{d}$ or Control+20 mL SO/head/d.

Means at the same row with different superscripts are significantly $(\mathrm{p}<0.05)$ different.

whole seeds (Beauchemin et al., 2009).

Increased milk fat concentration for SS or SO goats could be related to more $\mathrm{C} 2$ produced in the rumen of goats fed diets with SS or SO addition. Increased milk lactose and fat contents with the SO addition may be due to the increased blood serum glucose concentration and increased rumen fermentation with SO goats (Ollier et al., 2009). In addition, Sanz Sampelayo et al. (2002) reported a high correlation coefficient $(r=0.95)$ between lactose production and fat supplementation in goats fed isocaloric diets.

Increased concentrations of milk C6:0, C8:0, C14:1, and C16:1, C18:1n9c FA and TUFA with decreasing C17:0 concentrations were obtained with SO goats. Moreover, both of SO and SS had increased C18:2 trans-10, cis-12, C18:3N3 and total CLA concentrations compared to Control (Table 5). Fatty acids can be originated from plasma $(60 \%)$ or by the synthesis in the mammary gland from acetate and hydroxybutyrate originated from rumen fermentation involving acetyl CoA carboxylase enzymes and fatty acid synthetase (Mesquita et al., 2008; Kholif et al., 2014). Polyunsaturated FA are not synthesized by ruminants, so that their concentration in milk depends on the amount of PUFA absorbed from the intestines. Milk from goats receiving sunflower seeds or oil supplementation displayed an improvement in the FA profile, with an increased PUFA and monounsaturated FA contents and a decreased in SFA content. These results are in agreement with other studies (Castro et al., 2009; Mohammed et al., 2011), which reported similar changes in milk fat when sunflower seeds supplements were used. In the present study, the decreased C14:0 and C16:0 FA
Table 5. Milk fatty acids profile of lactating Damascus goats fed basal diet with sunflower seeds whole (SS) or sunflower seeds oil (SO)

\begin{tabular}{|c|c|c|c|c|c|}
\hline \multirow{2}{*}{ Item } & \multicolumn{3}{|c|}{ Diets $^{1}$} & \multirow{2}{*}{ SEM } & \multirow{2}{*}{ p-value } \\
\hline & Control & SS & $\mathrm{SO}$ & & \\
\hline$\overline{\mathrm{C}} 4: 0$ & 1.60 & 1.50 & 1.20 & 0.172 & 0.185 \\
\hline C6:0 & $1.26^{\mathrm{b}}$ & $1.50^{\mathrm{ab}}$ & $1.64^{\mathrm{a}}$ & 0.104 & 0.041 \\
\hline C8:0 & $2.62^{\mathrm{b}}$ & $2.26^{\mathrm{b}}$ & $2.84^{\mathrm{a}}$ & 0.114 & 0.039 \\
\hline C10:0 & 6.63 & 5.77 & 5.91 & 0.577 & 0.338 \\
\hline C12:0 & 3.12 & 3.76 & 3.29 & 0.344 & 0.698 \\
\hline C14:0 & 9.93 & 9.28 & 9.77 & 0.925 & 0.762 \\
\hline C14:1 & $0.14^{\mathrm{b}}$ & $0.18^{b}$ & $0.59^{\mathrm{a}}$ & 0.017 & 0.000 \\
\hline C15:0 & 0.28 & 0.28 & 0.37 & 0.151 & 0.140 \\
\hline C16:0 & 28.3 & 27.1 & 25.6 & 3.839 & 0.718 \\
\hline C16:1 & $0.17^{\mathrm{b}}$ & $0.21^{\mathrm{b}}$ & $0.88^{\mathrm{a}}$ & 0.027 & 0.000 \\
\hline C17:0 & $1.11^{\mathrm{a}}$ & $0.39^{\mathrm{b}}$ & $0.37^{\mathrm{b}}$ & 0.023 & 0.001 \\
\hline C18:0 & 14.33 & 12.51 & 11.65 & 3.530 & 0.547 \\
\hline C18:1N9T & 25.1 & 28.9 & 29.2 & 3.82 & 0.566 \\
\hline C18:1N9C & $3.97^{\mathrm{ab}}$ & $3.71^{\mathrm{b}}$ & $4.98^{\mathrm{a}}$ & 0.260 & 0.041 \\
\hline $\mathrm{C} 18: 2$ trans -10, cis -12 & $0.05^{\mathrm{b}}$ & $0.08^{\mathrm{a}}$ & $0.09^{\mathrm{a}}$ & 0.008 & 0.030 \\
\hline $\mathrm{C} 18: 2$ cis-9, trans -11 & 0.10 & 0.12 & 0.13 & 0.020 & 0.664 \\
\hline $\mathrm{C} 18: 3 \mathrm{~N} 3$ & $0.10^{\mathrm{b}}$ & $0.13^{\mathrm{a}}$ & $0.15^{\mathrm{a}}$ & 0.012 & 0.021 \\
\hline C18:3N6 & 0.30 & 0.42 & 0.43 & 0.058 & 0.166 \\
\hline C20:0 & 0.85 & 0.82 & 0.86 & 0.114 & 0.988 \\
\hline TSFA & 70.0 & 66.1 & 63.5 & 7.26 & 0.193 \\
\hline TUFA & $29.9^{\mathrm{b}}$ & $33.8^{\mathrm{ab}}$ & $36.4^{\mathrm{a}}$ & 5.76 & 0.031 \\
\hline MUFA & 29.4 & 33.1 & 35.6 & 5.68 & 0.277 \\
\hline PUFA & 0.55 & 0.75 & 0.80 & 0.096 & 0.147 \\
\hline Total CLA & $0.15^{\mathrm{b}}$ & $0.20^{\mathrm{a}}$ & $0.22^{\mathrm{a}}$ & 0.017 & 0.007 \\
\hline N6/N3 & 3.0 & 3.23 & 2.86 & 0.297 & 0.736 \\
\hline
\end{tabular}

SEM, standard error of the mean; TSFA, total saturated fatty acids; TUFA, total unsaturated fatty acids; MUFA, mono unsaturated fatty acids; PUFA, poly unsaturated fatty acids; CLA, conjugated linolenic acid.

${ }^{1}$ Diets consisted of concentrate feed mixture and fresh Trifolium alexandrinum (1:1; Control), or Control plus $50 \mathrm{~g} \mathrm{SS} / \mathrm{head} / \mathrm{d}$ or Control+20 mL SO/head/d.

Means at the same row with different superscripts are significantly $(\mathrm{p}<0.05)$ different.

contents in milk from goats fed SS or SO may be a positive goal from a human health perspective, because high proportions of C14:0 and C16:0 FA has been associated with human cardiovascular problems (Noakes et al., 1996). Moreover, the increased C18:1 content with SO and SS can be a result of partial biohydrogenation of $\mathrm{C} 18: 2$ and $\mathrm{C} 18: 3$ FA and of the desaturation of C18:0 in the mammary gland (Kennelly, 1996). Most of CLA isomers levels were increased when the goat fed diet added with sunflower whole seeds or oil. Mir et al. (1999) suggest that substantial increase in CLA content in milk of small ruminants can be achieved by feeding PUFA rich oilseeds. The increased dietary intake of $\mathrm{C} 18: 3$ with SS or SO resulted an increasing levels of C18:1 trans-11 and increased CLA C18:2 cis-9, trans-11 by $\Delta 9$-desaturase activity. There are 
some studies tried to increase milk content from CLA using a dietary addition with sunflower oil or sunflower whole seeds (Petit et al., 2004; Castro et al., 2009; Mohammed et al., 2011). Moreover, Omega 6 FA concentrations in milk were increased in SS or SO goats compared to Control goats. The omega 6 to omega 3 FA ratio in milk was affected by the diet, with treatments ranking from the highest to the lowest ratio as follows: Control $>\mathrm{SS}>\mathrm{SO}$.

\section{CONCLUSION}

It could be concluded that feeding diets added with a daily dose of SS $(50 \mathrm{~g} / \mathrm{h} / \mathrm{d})$ or $\mathrm{SO}(20 \mathrm{~mL} / \mathrm{h} / \mathrm{d})$ increased milk production and milk fat content. Moreover, both additives decreased total saturated fatty acid and increased total CLA and TUFA in milk with more beneficial effects for SO than SS. More studies are required for the long term beneficial effects of sunflower whole seeds and seeds oil in the diets of dairy goats.

\section{REFERENCES}

AbuGhazaleh, A. A. and L. D. Holmes. 2007. Diet supplementation with fish oil and sunflower oil to increase conjugated linoleic acid levels in milk fat of partially grazing dairy cows. J. Dairy Sci. 90:2897-2904.

AOAC. 1997. Official Methods of Analysis. 16th ed. Association of Official Analytical Chemists, Arlington, VA, USA.

AOAC. 2007. Official Methods of Analysis. 19th ed. Association of Official Analytical Chemists, Washington, DC, USA.

Baile, C. A. and J. M. Forbes. 1974. Control of feed intake and regulation of energy balance in ruminants. Physiol. Rev. 54:160-214.

Beauchemin, K. A., S. M. McGinn, C. Benchaar, and L. Holtshausen. 2009. Crushed sunflower, flax, or canola seeds in lactating dairy cow diets: Effects on methane production, rumen fermentation, and milk production. J. Dairy Sci. 92:2118-2127.

Castro, T., T. Manso, V. Jimeno, M. Del Alamo, and A. R. Mantecon. 2009. Effects of dietary sources of vegetable fats on performance of dairy ewes and conjugated linoleic acid (CLA) in milk. Small Rumin. Res. 84:47-53.

Chilliard, Y., F. Glasser, A. Ferlay, L. Bernard, J. Rouel, and M. Doreau. 2007. Diet, rumen biohydrogenation and nutritional quality of cow and goat milk fat. Eur. J. Lipid Sci. Technol. 109:828-855.

Chilliard, Y., J. Rouel, A. Ferlay, L. Bernard, P. Gaborit, K. Raynal-Ljutovac, A. Lauret, and C. Leroux. 2006. Optimising goat's milk and cheese fatty acid composition. In: Improving the Fat Content of Foods (Eds. C. Williams and J. Buttriss). Woodhead Publishing Ltd., Cambridge, UK. pp. 123-145.

Clark, J. H., H. R. Spires, R. G. Derring, and M. R. Bennink. 1977. Milk production, nitrogen utilization and glucose synthesis in lactating cows infused postruminally with sodium caseinate and glucose. J. Nutr. 107:631-644.

Dixit, S. J., K. K. Appu Kuttan, and K. Singh. 2012. Study of human allergic milk whey protein from different mammalian species using computational method. Bioinformation 8:10351041.

Dschaak, C. M. 2009. Production Performance and Profiles of Milk Fatty Acids of Lactating Dairy Cows Fed Whole Safflower Seed Containing High Fat and Low Fiber. Master's Thesis, Utah State University, Logan, UT, USA.

Duncan, D. B. 1955. Multiple range and multiple $F$ test. Biometrics 11:1-42.

Ebrahimi, M., M. A. Rajion, and Y. M. Goh. 2014. Effects of oils rich in linoleic and $\alpha$-linolenic acids on fatty acid profile and gene expression in goat meat. Nutrients 6:3913-3928.

Flatt, W. P., R. G. Warner, and J. K. Loosli. 1956. Absorption of volatile fatty acids from the reticulo-rumen of young dairy calves. J. Dairy Sci. 39:928.

Fulton, W. R., T. J. Klopfenstein, and R. A. Britton. 1979. Adaptation to high concentrate diets by beef cattle: II. Effect of ruminal $\mathrm{pH}$ alteration on rumen fermentation and voluntary intake of wheat diets. J. Anim. Sci. 49:785-789.

ISO-IDF. 2002. Milk fat-preparation of fatty acid methyl esters. International Standard ISO 15884-IDF 182:2002.

Ivan, M., P. S. Mir, Z. Mir, T. Entz, M. L. He, and T. A. McAllister. 2004. Effects of dietary sunflower seeds on rumen protozoa and growth of lambs. Br. J. Nutr. 92:303-310.

Kennelly, J. J. 1996. The fatty acid composition of milk fat as influenced by feeding oilseeds. Anim. Feed Sci. Technol. 60: 137-152.

Khattab, H. M., H. M. Gado, A. E. Kholif, A. M. Mansour, and A. M. Kholif. 2011. The potential of feeding goats sun dried rumen contents with or without bacterial inoculums as replacement for berseem clover and the effects on milk production and animal health. Int. J. Dairy Sci. 6:267-277.

Kholif, A. E., H. M. Khattab, A. A. El-Shewy, A. Z. M. Salem, A. M. Kholif, M. M. El-Sayed, H. M. Gado, and M. D. Mariezcurrena. 2014. Nutrient digestibility, ruminal fermentation activities, serum parameters and milk production and composition of lactating goats fed diets containing rice straw treated with Pleurotus ostreatus. Asian Australas. J. Anim. Sci. 27:357-364.

Kholif, S. M., T. A. Morsy, O. H. Matloup, H. M. Ebeid, and A. M. Kholif. 2015. Effects of crushed linseed or linseed oil supplementation on performance of dairy goats and fatty acid profile in milk. Life Sci. J. 12:94-99.

Mesquita, I. V. U., R. G. Costa, R. de Cássia Ramos do Egypto Queiroga, A. N. de Medeiros, and A. R. P. Schuler. 2008. Profile of milk fatty acids from moxotó goats fed with different levels of manicoba (Manihot Glaziovii Muel Arg.) silage. Braz. Arch. Biol. Technol. 51:1163-1169.

Mir, Z., L. A. Goonewardene, E. Okine, S. Jaegar, and H. D. Sceer. 1999. Effect of feeding canola oil on constituents, conjugated linoleic acid (CLA) and long chain fatty acids in goats milk. Small Rumin. Res. 33:137-143.

Mohammed, R., S. M. McGinn, and K. A. Beauchemin 2011. Prediction of enteric methane output from milk fatty acid concentrations and rumen fermentation parameters in dairy cows fed sunflower, flax, or canola seeds. J. Dairy Sci. 94:6057-6068.

Ney, D. M. 1991. Potential for enhancing the nutritional properties of milk fat. J. Dairy Sci. 74:4002-4012.

Noakes, M., P. J. Nstel, and P. M. Clifton. 1996. Modifying the 
fatty acid profile of dairy products through feedlot technology lowers plasma cholesterol of humans consuming the products. Am. J. Clin. Nutr. 63:42-46.

NRC. 2007. Nutrient Requirements of Small Ruminants. National Academy Press. Washington, DC, USA.

Ollier, S., C. Leroux, A. de la Foye, L. Bernard, J. Rouel, and Y. Chilliard. 2009. Whole intact rapeseeds or sunflower oil in high-forage or high-concentrate diets affects milk yield, milk composition, and mammary gene expression profile in goats. J. Dairy Sci. 92:5544-5560.

Ørskov, E. R. and R. Ryle. 1990. Energy Nutrition in Ruminants. Elsevier Science Publishers, New York, USA.

Peng, Y. S., M. A. Brown, J. P. Wu, and Z. Liu. 2010. Different oilseed supplements alter fatty acid composition of different adipose tissues of adult ewes. Meat Sci. 85:542-549.

Petit, H. V., C. Germiquet, and D. Lebel. 2004. Effect of feeding whole, unprocessed sunflower seeds and flaxseed on milk production, milk composition, and prostaglandin secretion in dairy cows. J. Dairy Sci. 87:3889-3898.
Petit, H. V. 2003. Digestion, milk production, milk composition, and blood composition of dairy cows fed formaldehyde treated flaxseed or sunflower seed. J. Dairy Sci. 86:2637-2646.

Rafalowski, W. and C. S. Park. 1982. Whole sunflower seed as a fat supplement for lactating cows. J. Dairy Sci. 65:1484-1492.

Sanz Sampelayo, M. R., L. Pérez, J. J. Martin Alonso, L. Amigo, and J. Boza. 2002. Effects of concentrates with different contents of protected fat rich in PUFAs on the performance lactating Granadina goats. Part II. Milk production and composition. Small Rumin. Res. 43:141-148.

SAS, 2006. SAS User's Guide: Statistics. Ver 9.0. SAS Institute, Cary, NC, USA.

Satter, L. D. and L. L. Slyter. 1974. Effect of ammonia concentration on rumen microbial protein production in vitro. Br. J. Nutr. 32:199-208.

Steel, R. G. D. and J. H. Torrie. 1980. Bioestadística: Principios y Procedimientos. McGraw-Hill, Mexico City, México. pp. 181184. 